\title{
Limnological variables and nutritional content of submerged aquatic macrophytes in a tropical lagoon
}

\author{
Variáveis limnológicas e conteúdo nutricional de \\ macrófitas aquáticas submersas em uma lagoa tropical
}

Bruno dos Santos Esteves ${ }^{1}$ and Marina Satika Suzuki ${ }^{2}$

${ }^{1}$ Programa de Pós-graduação em Ecologia e Recursos Naturais,

Laboratório de Ciências Ambientais, Centro de Biociências e Biotecnologia - CBB,

Universidade Estadual do Norte Fluminense "Darcy Ribeiro" - UENF,

Av. Alberto Lamego, 2000, Pq. Califórnia, Campos dos Goytacazes, RJ, Brazil

e-mail: brunosnts@yahoo.com.br

${ }^{2}$ Laboratório de Ciências Ambientais, Centro de Biociências e Biotecnologia - CBB, Universidade Estadual do Norte Fluminense "Darcy Ribeiro" - UENF,

Av. Alberto Lamego, 2000, Pq. Califórnia, Campos dos Goytacazes, RJ, Brazil e-mail: marina@uenf.br

\begin{abstract}
Aim: The aim of this study was to evaluate elemental composition (C, N and P) and carbohydrate and lipids content of aquatic macrophytes Egeria densa, Ceratophyllum demersum and Najas marina found in a lagoon of Norte Fluminense and relate these data to limnological parameters measured in the same period; Methods: The samples were obtained from 10 sites throughout the lagoon in July/2001 (dry season) and January/2002 (rainy season) with determinations limnological parameters and quantification of nutrient content and biochemical composition of the aquatic macrophytes; Results: High values of electrical conductivity and alkalinity explain the spatial distribution of the studied macrophytes; and the $\mathrm{pH}$ values $(<9.0)$, $\mathrm{O}_{2}$ super-saturation and $\mathrm{CO}_{2}$ sub-saturation suggest a high primary production of both phytoplankton and submersed aquatic macrophytes. For nutrients assessed on aquatic macrophytes, significant seasonal variations were observed in total phosphorus content $(\mathrm{p}<0.05)$, total nitrogen and total carbon, however, without a clear pattern between seasons and macrophytes There was a tendency to higher concentrations of $P$ in the tissues of macrophytes in the rainy season, as well as carbohydrates and lipids, suggesting that this period presents better conditions to Ceratophyllum demersum and Egeria densa development in the Campelo Lagoon; Conclusions: There was no clear association between the nutrient content and reserves found in macrophytes with limnological and environmental parameters.
\end{abstract}

Keywords: aquatic macrophytes, elemental composition, Ceratophyllum demersum, Egeria densa, Najas marina.

Resumo: Objetivo: $\mathrm{O}$ objetivo deste estudo foi avaliar a composição elementar (C, $\mathrm{N}$ e P) e conteúdo de carboidratos e lipídeos das macrófitas aquáticas Egeria densa, Ceratophyllum demersum e Najas marina encontradas em uma lagoa do Norte Fluminense, e relacionar esses dados a parâmetros limnológicos medidos em igual período; Métodos: As amostras foram obtidas em julho/2001 (período seco) e janeiro/2002 (período chuvoso), em 10 pontos ao longo da lagoa do Campelo com determinaçóes de parâmetros limnológicos e quantificaçâo de componentes nutricionais e bioquímicos das macrófitas aquáticas; Resultados: Elevados valores de condutividade elétrica e alcalinidade explicam a distribuição espacial das macrófitas estudadas, e os valores de $\mathrm{pH}(<9,0)$, supersaturação de $\mathrm{O}_{2}$ e subsaturação de $\mathrm{CO}_{2}$ sugerem uma elevada produçáo primária, tanto fitoplanctônica quanto de macrófitas submersas. Para os nutrientes avaliados nas macrófitas aquáticas, variaçóes sazonais significativas foram observadas no conteúdo de fósforo total $(\mathrm{p}<0,05)$, de nitrogênio total e carbono total, entretanto, sem qualquer padrão definido entre períodos sazonais e macrófitas. Observou-se tendência às maiores concentraçóes de P nos tecidos das macrófitas no período chuvoso, assim como carboidratos e lipídeos, sugerindo que este período é mais propício ao desenvolvimento de Ceratophyllum demersum e Egeria densa na lagoa do Campelo; Conclusóes: Não se observou uma clara associação entre os conteúdos nutricionais e de reservas encontrados nas macrófitas com as variáveis limnológicas e ambientais medidas.

Palavras-chave: macrófitas aquáticas, composição elementar, Ceratophyllum demersum, Egeria densa, Najas marina. 


\section{Introduction}

The development of submerged aquatic macrophytes in lentic aquatic ecosystems is an intricate process, as it involves interaction among physiological processes (respiration and primary production), physical variables (light, temperature and sediment), chemical variables $(\mathrm{pH}$, alkalinity and electrical conductivity) and ecological factors (competition and herbivory) (Howard and Rafferty, 2006). When submersed aquatic macrophytes are established, they have an effect on the quality of the water and they are fundamental to the integrated management of the ecosystem (Jeppesen et al., 1998).

Aquatic macrophytes play a fundamental role in the nutrient cycling of water bodies as well as in the creation of habitats for many animals. Furthermore, they form mixed or monospecific stands where they influence water physics and chemistry, altering the temperature, turbulence, penetration of sunlight, concentration and distribution of dissolved oxygen and nutrients (Pompêo and Moschini-Carlos, 2003). The content of nitrogen and phosphate, as well as the availability of underwater radiation are characteristically the most critical factors for the development of submerged macrophytes (Kasige and Takashi, 2009). Other relevant factors are the environmental gradients in dry and rainy periods, which may alter the availability of light as well as the dominant plant community in the environment. Light variation may serve as an indicator so that the plant alters its metabolic pathway and starts to transfer resources either to growth or to reproduction (Wang et al., 2008).

The aim of this study was to evaluate the nutritional content of submerged aquatic macrophytes, examining the possible variations between the rainy and dry seasons and their link with limnological variables, and exploring the possible limitations on the dominance of submerged aquatic macrophytes.

\subsection{Study area}

Campelo Lagoon is located in the Paraíba do Sul Northern delta, between Campos dos Goytacazes and Sáo Francisco do Itabapoana municipalities $\left(21^{\circ} 38^{\prime}-21^{\circ} 42^{\prime} \mathrm{S}\right.$ and $\left.41^{\circ} 08^{\prime}-41^{\circ} 12^{\prime} \mathrm{W}\right)$; its surface area is approximately $12 \mathrm{~km}^{2}$, representing one of the largest local lagoons (Figure 1). It is considered to be a typical continental sand plain lagoon. Its catchment area is mainly used for pasture and monoculture of sugarcane. Along its entire marginal area it is possible to observe the existence of dense colonization of the aquatic macrophyte Typha dominguensis Pers. Other macrophytes are found around the lagoon as Bacopa arenaria (J.A. Schmidt) Loefgr. \& Edwall., Justicia laevilinguis (Nees ex Mart.) Lindau. and Mimosa nigra Hub. Cyperus giganteus Vahl., Eichhornia crassipes (Martius) Solms-Laubach., Eleocharis acutangula (Roxb.) Schult., Nymphoides indica (L.) O. Kuntze. and Scirpus californicus (C.A. Mey.) Steud. are found in the shallow flood areas; and Salvinia auriculata Aubl., Cabomba caroliniana A. Gray.

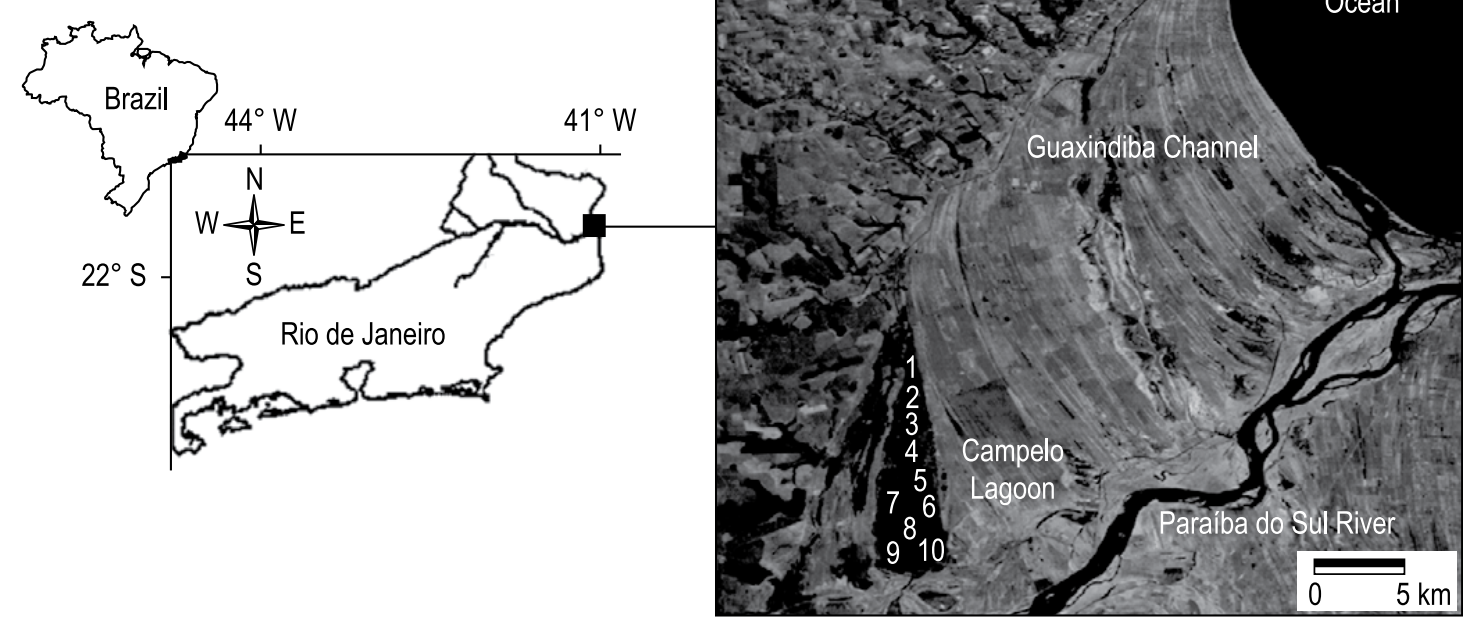

Figure 1. Map of the Campelo Lagoon and 10 sampling sites, State of Rio de Janeiro, Brazil. Source: Landsat 7. 
and Utricularia foliosa L. in the deep littoral zone. The main macrophytes in the lagoon are submersed Ceratophyllum demersum L., Egeria densa Planch. and Najas marina L. that represent the main primary producers of the Campelo lagoon.

Campelo Lagoon lies in a region that presents tropical climate with annual average rainfall of $1,000 \mathrm{~mm}$ and average temperatures between 20 and $30^{\circ} \mathrm{C}$ (FIDERJ, 1978). The highest rainfall incidence occurs from November to January, decreasing in February and increasing again in March and April. Between May and August decreased rainfall characterizes the dry season (rainy: $155 \mathrm{~mm}$ and dry: $1 \mathrm{~mm}$ ). The local soil is sandy and poor in nutrients (podzol hydromorphic - CIDE, 1997).

Campelo was one of the lagoons that suffered the consequences of extensive local works performed by DNOS (Departamento de Obras e Saneamento). The construction of channels, dikes and sluices resulted in drastic reduction of the water surface as well as the amount of fish, since DNOS works blocked water intake and "piracema" (fish spawning) during the flood seasons (Bernardes and Barroso, 1995). On the other hand, it promoted water drainage especially through Guaxindiba Channels. The water column reduction may have promoted the intense development of submerged macrophytes, which make a large number of habitats, presenting a refuge for many organisms. The studies of submerged vegetation have an important role in determining seasonal variation of ecological variability in Campelo lagoon.

\section{Material and Methods}

The samplings performed in Campelo Lagoon occurred during two seasons: dry and rainy. So, there were samplings in the summer, when the highest rainfall occurs, and in the winter, when the lowest rainfall occurs. Thus, ten sampling sites were established and distributed along the longitudinal gradient of Campelo Lagoon. Sites 1, 2 and 3 are located from the northernmost (Guaxindiba Channel terminus) to the middle portion of the lagoon, sites 4, 5, 6, 7 and 8 in the middle portion of the lagoon, and sites 9 and 10 in the southern portion, under the influence of the Paraíba do Sul River freshwater in the rainy season. Three water samplings were performed in the lagoon in the dry season in $2001(04 / 07 / 01,18 / 07 / 01$ and 01/08/01) and three samplings in the rainy season in 2002 $(11 / 01 / 02,28 / 01 / 02$ and $06 / 02 / 02)$.
In the field, temperature and dissolved oxygen (DO) through oxymeter YSI model 55, electrical conductivity and $\mathrm{pH}$ through multiparameter YSI model 63 were directly measured in the water body. The water samples were directly collected with one-liter polyethylene bottles, cooled down and taken to the laboratory. Total alkalinity determination was performed by potentiometric titration (Gran, 1952); from total alkalinity data, $\mathrm{pH}$ and temperature, $\mathrm{CO}_{2}$ saturation values in the water column were calculated according to Carmouze (1994). A subaliquot was filtered under vacuum, in triplicate, through Whatman GF/F $(-0.7 \mu$ m of porosity) filter. The filters were immediately frozen (at $-4{ }^{\circ} \mathrm{C}$ in a freezer) for further determination of chlorophyll- $a$ concentration, according to the methodology described by Nusch and Palme (1975) which is based on the extraction with hot ethanol $\left(80^{\circ} \mathrm{C}\right)$. Determinations of dissolved nutrients, as orthophosphate and ammonium, in triplicate, were performed according to the methodology described in Strickland and Parsons (1978) and Grasshoff et al. (1983), as well as nitrate and nitrite which were determined in continuous flow system FIA ASIA ISMATEC (production of colored complex azo) in triplicate. For determination of dissolved organic carbon (DOC), another aliquot of filtered water was used and preserved in amber bottles, $5 \mu \mathrm{L}$ of $\mathrm{H}_{3} \mathrm{PO}_{4}$ $10 \%$ added to each $\mathrm{mL}^{-1}$ of sample, and kept under refrigeration until analysis. DOC was determined after acidification with $\mathrm{HC} 12 \mathrm{~N}$ and after ultra pure air purge by catalytic oxidation at high temperature in TOC-500 (Shimadzu) analyzer.

The submerged aquatic macrophytes were manually collected from each site for quantification of nutrient content (carbon, nitrogen and phosphorus) and biochemical composition (soluble carbohydrates and total lipids). Aquatic macrophytes were separated by genus and washed under running water for removal of attached inorganic and organic matter, dried in circulation oven at $40{ }^{\circ} \mathrm{C}$ until constant weight (Esteves et al., 2005); then, the macrophytes were ground in knife mill. After these procedures, sub aliquots were separated for determination of carbon, nitrogen, phosphorus, lipids and soluble carbohydrates in these different samples. Total carbon and nitrogen were determined through Perkin Elmer 2400 (CHNS/O) elemental analyzer, and phosphate, after acid digestion, was determined through spectrophotometric reading of colored complex at $885 \mathrm{~nm}$ (Delgado et al., 1994) in triplicate. Total lipids were determined by chlorophorm: methanol solution $(1: 2)$ and 
gravimetric method, using the collected material triplicates (Herbreteau et al., 1997); soluble carbohydrate content was determined by the phenol-sulfuric acid reaction method (Dubois et al., 1956) and the spectrophotometric reading of the extract at $490 \mathrm{~nm}$ (Delgado et al., 1994) in triplicate.

Test $\mathrm{F}$ was applied, as one of the assumptions for test- $t$ use, together with the normality test and homoscedasticity of data. The significance level adopted was 0.05 , being applied to the physiochemical variables of the water and to the elemental contents and biochemical classes of macrophytes in order to check differences among the sampling periods. Pearson correlation was used for checking associations between the studied variables, using the same significance level.

\section{Results}

Macro-climatic variation was observed among the studied periods: the water temperature average was $22.9^{\circ} \mathrm{C}$ in the dry period and $28.5^{\circ} \mathrm{C}$ in the rainy period $(p<0.001)$. Unlike the water temperature, the electrical conductivity values presented a spatial variation, reflecting the marine influence that occurred until April/2001 in the northern portion of the lagoon. Thus, conductivity values decreased from site $1\left(>3,000 \mu \mathrm{S} . \mathrm{cm}^{-1}\right)$ to the southern portion (sites 9 and 10). Besides spatial gradient observed in both studied periods, significantly higher electrical conductivity values were found in the dry period $\left(>2,000 \mu \mathrm{S} . \mathrm{cm}^{-1}\right)$ $(\mathrm{p}=0.006)$, decreasing in the rainy period (bellow to $\left.190 \mu \mathrm{S} . \mathrm{cm}^{-1}\right)$ as consequence of the largest inflow and accumulation of fresh water from catchment area and from Paraíba do Sul River.

Alkalinity also presented spatial and temporal variations, decreasing its values southward and in the rainy period; it was also consequence of the largest inflow of freshwater (values between 1.5 and $3.0 \mathrm{mEq} \cdot \mathrm{L}^{-1}$ in the dry period as well as between 0.6 and $2.2 \mathrm{mEq} . \mathrm{L}^{-1}$ in the rainy period - Figure 2). These variables presented significant differences among the studied periods $(\mathrm{p}<0.0001)$. The variables $\mathrm{CO}_{2}$ and $\mathrm{pH}$ did not present significant differences among the studied periods. DO (dissolved oxygen) saturation (average of $116 \%$ sat. in the dry period and $84 \%$ sat. in the rainy period) associated with chlorophyll- $a$ high values (between 10.2 and $64.7 \mu \mathrm{g} . \mathrm{L}^{-1}$, average of $41.4 \mu \mathrm{g} . \mathrm{L}^{-1}$ in the dry period and between 1.7 and $28.9 \mu \mathrm{g} . \mathrm{L}^{-1}$, average of $16,4 \mu \mathrm{g} . \mathrm{L}^{-1}$ in the rainy period) suggest that autotrophic metabolism was predominant in the system during some sampling periods as well as the positive correlation between $\mathrm{DO}$ and $\mathrm{pH}(\mathrm{r}=0.60$; $\mathrm{p}=0.005, \mathrm{n}=20)$ and negative one between DO and $\mathrm{CO}_{2}(\mathrm{r}=-0.69 ; \mathrm{p}=0.0007 ; \mathrm{n}=20)$ indicate the dominance of biological processes driving the lagoon dynamic.

All chemical determinations were performed in triplicate (CV usually lower than 5\%) and the values found in this study represent average of the obtained values. Among dissolved nutrients, dissolved organic carbon (DOC) presented significant temporal variation $(\mathrm{p}=0.004)$ as well as spatial variation (values between 10.3 and $28.6 \mathrm{mg} . \mathrm{L}^{-1}$ in the dry period, and 6.0 and $22.1 \mathrm{mg} . \mathrm{L}^{-1}$ in the rainy period), following observed tendency for electrical conductivity and total alkalinity $(r>0.9$, $\mathrm{p}<0.0001, \mathrm{n}=20$ ). In addition, positive correlation between chlorophyll- $a$ and DOC concentrations $(\mathrm{r}=0.68, \mathrm{p}=0.001, \mathrm{n}=20)$ was observed, which indicates that phytoplankton activity may directly interfere in DOC availability in Campelo Lagoon. Ammonium, nitrate and nitrite also presented significant difference among the studied periods $(\mathrm{p}<0.05)$ (Figure 3) and decrease tendencies in its concentrations from north to south portion. Phosphate did not present significant differences among the studied periods $(\mathrm{t}, \mathrm{n}=20, \mathrm{p}=0.71)$ (Figure 3).

In order to analyze nutritional content of aquatic macrophytes sampled in Campelo Lagoon, average values to each element per sampling period were used, as no pattern in spatial variation was observed despite occurrence of coefficients of variation from 15 to $50 \%$ in up to $30 \%$ of cases. Carbon presented mean values that varied between $290 \mathrm{mg} \cdot \mathrm{g}^{-1} \mathrm{DW}$ in $N$. marina and $355 \mathrm{mg} \cdot \mathrm{g}^{-1} \mathrm{DW}$ in $C$. demersum, but significant differences for $C$. demersum, $E$. densa and $N$. marina (Figure 4) $(\mathrm{p}>0.05)$ were not observed among the sampling periods. Nitrogen found in submerged macrophytes showed averages varying between $18.6 \mathrm{mg} \cdot \mathrm{g}^{-1} \mathrm{DW}$ in $N$. marina and $27.6 \mathrm{mg} \cdot \mathrm{g}^{-1} \mathrm{DW}$ in $E$. densa, and decrease pattern from dry to rainy season. The mean nitrogen content of $C$. demersum was $22.8 \mathrm{mg}^{-1} \mathrm{~g}^{-1} \mathrm{DW}$. Seasonally, $C$. demersum and $E$. densa showed nitrogen lower values in the rainy period, but only E. densa presented significant differences in nitrogen concentrations in the tissues $(\mathrm{p}<0.05)$.

The phosphorus content presented higher values in rainy period for all macrophytes, showing significant differences in $E$. densa and N. marina tissues (Figure 4). Phosphorus values in the biomass of macrophytes varied between 

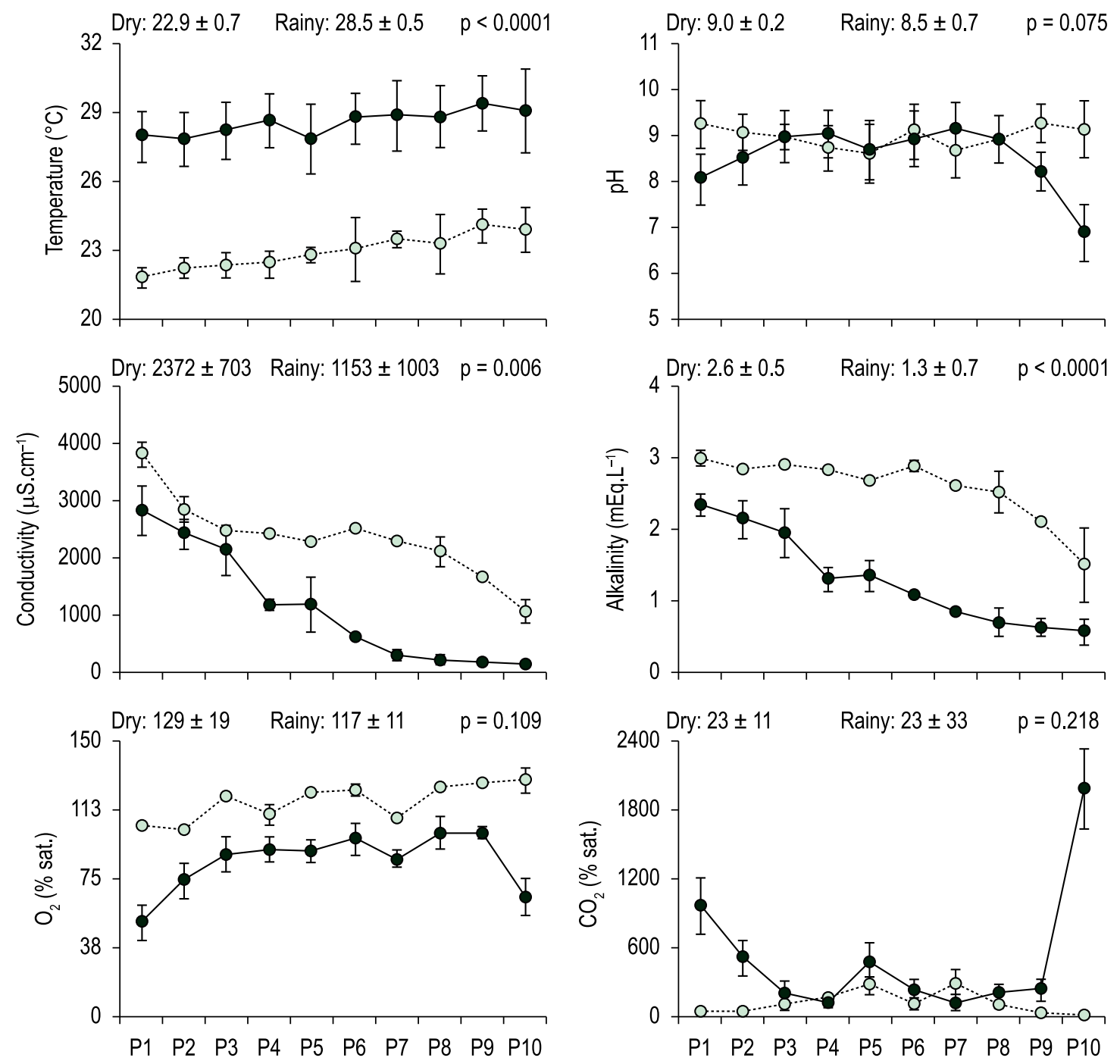

\section{○ Dry • Rainy}

Figure 2. Temperature, electrical conductivity, alkalinity, $\mathrm{pH}, \mathrm{O}_{2}$ and $\mathrm{CO}_{2}$ in Campelo Lagoon in dry (July/2001) and rainy (January/2002) season. The vertical bars represent the standard deviation. Mean \pm standard deviation values for each season and significance level.

$2.2 \mathrm{mg} \cdot \mathrm{g}^{-1} \mathrm{DW}\left(C\right.$. demersum) and $6.1 \mathrm{mg} \cdot \mathrm{g}^{-1} \mathrm{DW}$ (E. densa and N. marina - dry period). The mean concentrations of carbohydrates concentrations in C. demersum, E. densa and N. marina (Figure 5) were: $115 \pm 74 \mathrm{mg} \cdot \mathrm{g}^{-1} \mathrm{DW}, 108 \pm 71 \mathrm{mg} \cdot \mathrm{g}^{-1} \mathrm{DW}$ and $228 \pm 49 \mathrm{mg} \cdot \mathrm{g}^{-1} \mathrm{DW}$, with significant difference between seasons for $C$. demersum and $E$. densa.

\section{Discussion}

In Campelo Lagoon, at sampling time, aquatic macrophytes presented zonation, since the genera $C$. demersum and $N$. marina were observed throughout the lagoon, while $E$. densa was only observed from site 4 on in both sampling periods - i.e. sites that presented lower electrical conductivity values $\left(<2,440 \mu \mathrm{S} . \mathrm{cm}^{-1}\right)$, suggesting that this genus had been negatively affected by factors such as higher salt concentration mainly, higher total alkalinity values $\left(<2.8 \mathrm{mEq} . \mathrm{L}^{-1}\right)$. Yarrow et al. (2009) describe E. densa as highly adaptable, being found throughout the world, except Antarctica, in a wide variety of physic-chemical sub-aquatic environments. Hauenstein and Ramírez (1986) found that $E$. densa tolerated salinities up to 5 , growing naturally in the Valdivia river basin, but in laboratory salinity greater than 1 showed a slight inhibition of photosynthesis, growth and adventitious root production. Under competitive 

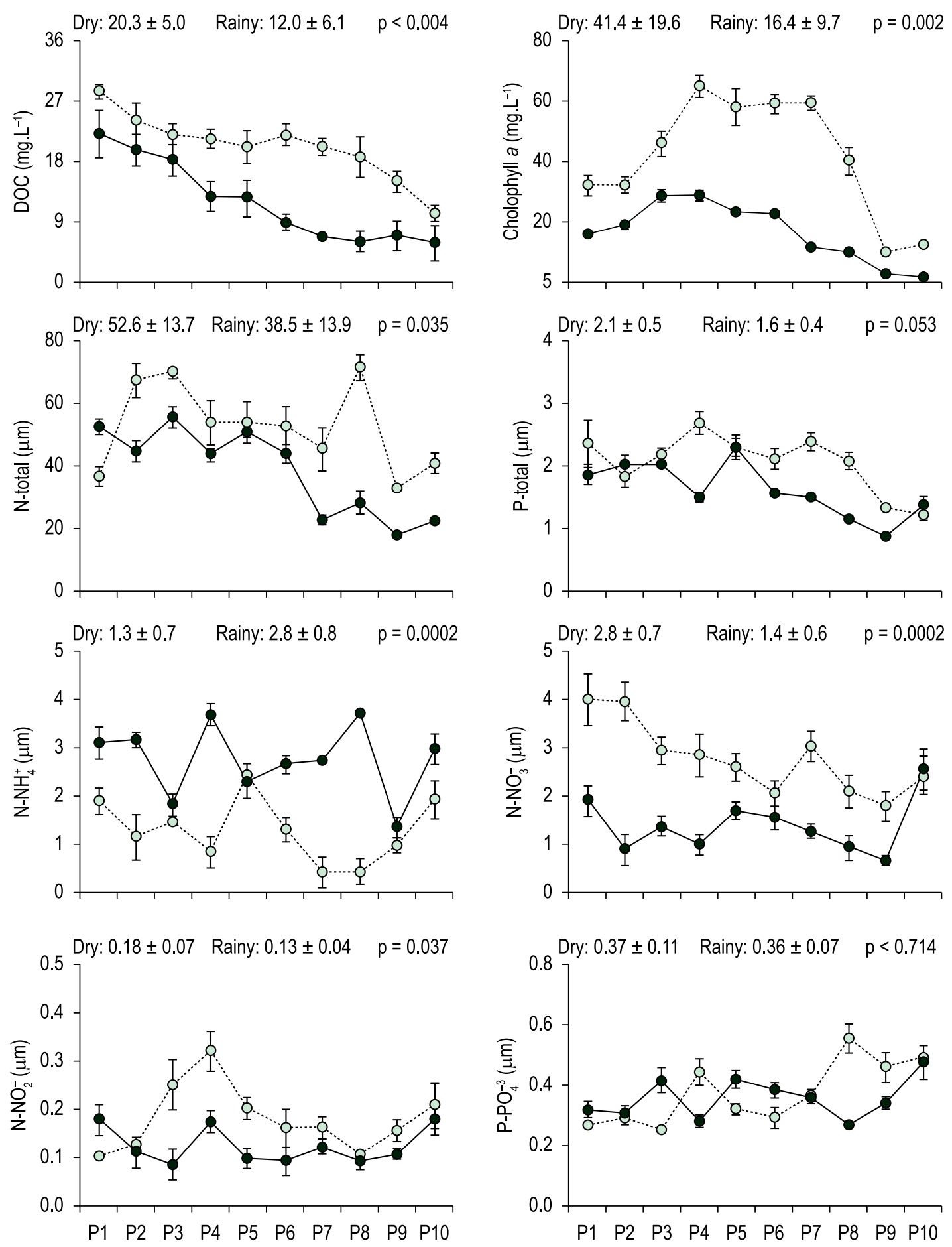

○ Dry • Rainy

Figure 3. DOC, chlorophyll- $a$, N-total, P-total, ammonium, nitrate, nitrite and orthophosphate in Campelo Lagoon in dry (July/2001) and rainy (January/2002) season. The vertical bars represent the standard deviation. Mean \pm standard deviation values for each season and significance level.

conditions, this inhibition can cause decline and/or no development of $E$. densa, as observed in Campelo Lagoon. Several studies describe C. demersum and $N$. marina development in high alkalinity, $\mathrm{pH}$ and brackish waters (Goulder and Boatman, 1971; Kipriyanova et al., 2007; Moreno-Ostos et al., 2007 among others), common feature of Campelo Lagoon. 

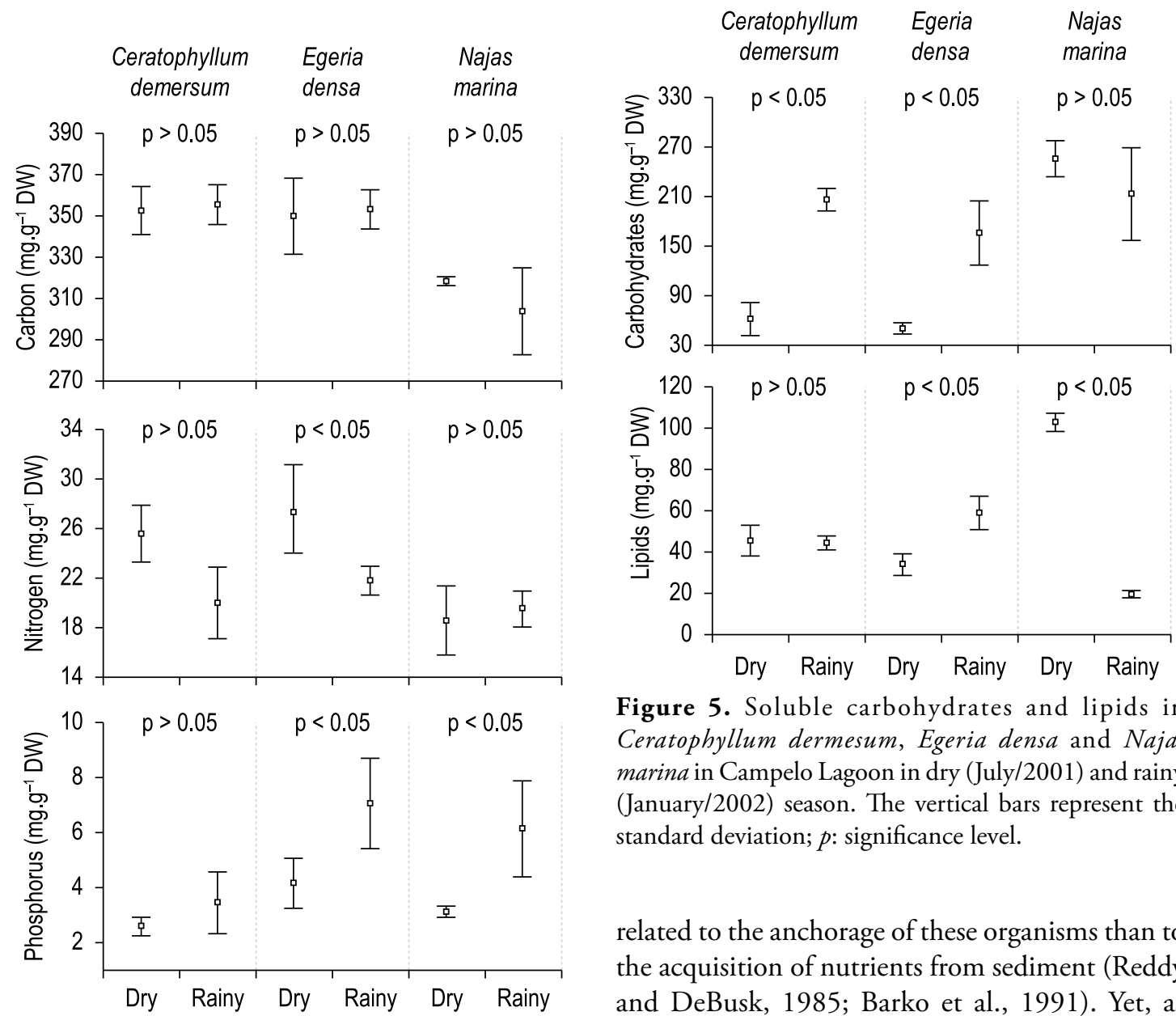

Figure 5. Soluble carbohydrates and lipids in Ceratophyllum dermesum, Egeria densa and Najas marina in Campelo Lagoon in dry (July/2001) and rainy (January/2002) season. The vertical bars represent the standard deviation; $p$ : significance level.

Figure 4. Carbon, nitrogen and phosphorus in Ceratophyllum dermesum, Egeria densa and Najas marina in Campelo Lagoon in dry (July/2001) and rainy (January/2002) season. The vertical bars represent the standard deviation; p: significance level.

The carbon values obtained for aquatic macrophytes do not differ from those described by other authors (Figure 6) (Baldantoni et al., 2004; Benoît et al., 2007), suggesting that these are intrinsic to the studied plants. Nitrogen found in submerged macrophytes of Campelo Lagoon is like ones found in the literature (Figure 7) (Kufel and Ozimek 1994, Greenway and Wooley, 1999; Baldantoni et al., 2004). The higher nitrogen concentrations in plant tissue in the dry period may be related to higher nitrate availability in the water, but this statement is not corroborated by Feijoó et al. (2002) that founded that E. densa absorb more ammonium than nitrate. It is worth remembering that $C$. demersum is a non-rooted submerged macrophyte, which depends on nutrient availability in the water column (Aravind and Prasad, 2005), and the development of roots, visually discreet in $E$. densa, may have been more

related to the anchorage of these organisms than to the acquisition of nutrients from sediment (Reddy and DeBusk, 1985; Barko et al., 1991). Yet, as $N$. marina is a rooted macrophyte, it can take its nutrient supply from sediment, which explains non-significant variation in nitrogen content found among the sampling periods.

The different pattern observed to nitrogen and phosphorus content in the macrophytes tissues was unexpected and not correlated to dissolved forms availability in water, as described in several studies (Goulder and Boatman, 1971; Barko and Smart, 1981; Carr et al., 1997; Feijoó et al., 2002; Yarrow et al., 2009), impairing data interpretation. These data may indicate differentiated ecophysiological responses in the studied macrophytes and periods. The higher concentrations of phosphorus in $C$. demersum, $E$. densa and $N$. marina tissues in the rainy period have been higher than critical content of $1.3 \mathrm{mg} \cdot \mathrm{g}^{-1} \mathrm{DW}$ mentioned by Gerloff and Krombholz (1966). It can be related to period of higher metabolic activity of macrophytes in relation to the dry period, as corroborated by increment in carbohydrate contents, especially in $C$. demersum and $E$. densa (Figure 5). P increment in plant tissues has caught up with slight phosphorus availability increment in the water and with decrease of 


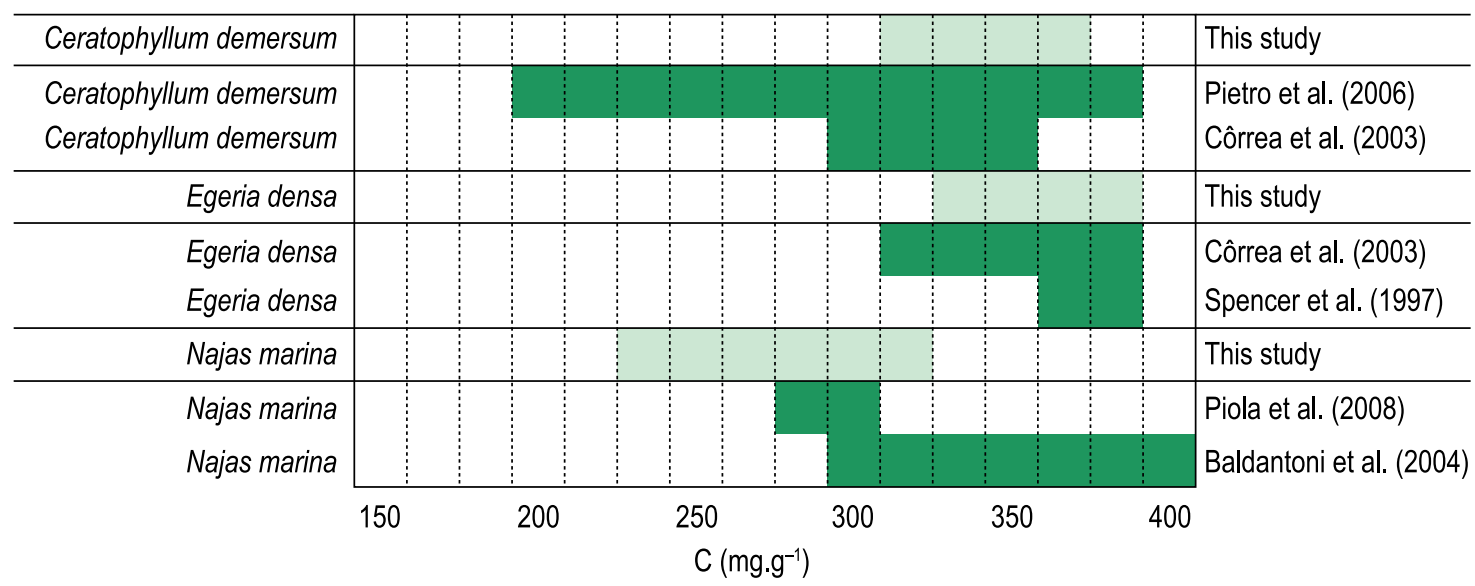

Figure 6. Carbon content in macrophytes, expressed as milligram per gram of dry matter $\left(\mathrm{mg} \cdot \mathrm{g}^{-1}\right)$, using data from this study and from literature.

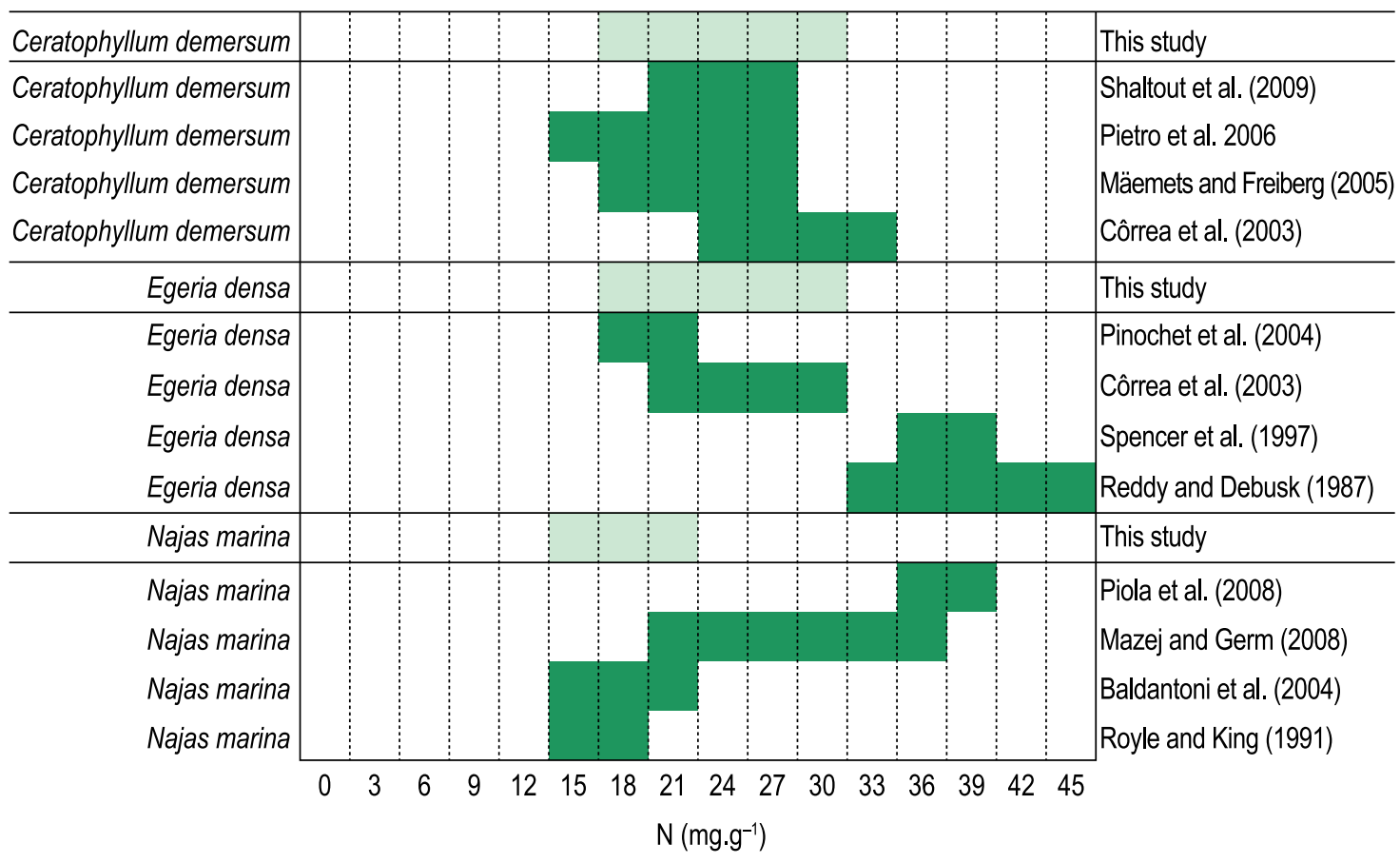

Figure 7. Nitrogen content in macrophytes, expressed as milligram per gram of dry matter (mg. $\left.\mathrm{g}^{-1}\right)$, using data from this study and from literature.

chlorophyll- $a$ and alkalinity values. Phosphorus values in the biomass of macrophytes of Campelo Lagoon is like ones found in the literature for same macrophytes (Figure 8) (Greenway and Wooley, 1999; Baldantoni et al., 2004), which suggests exceptional consumption (Ozimek et al., 1990) in periods of highest phosphate availability in the water, that far surpassed plant's instant nutritional requirements. Phosphorus cycling in lentic aquatic ecosystems has developed ability of macrophytes to absorb and store immense quantities of this nutrient
(Ni, 2001; Benoît et al., 2007) and can incorporate phosphorus in far above the optimum level to maintain upper limit growth of aquatic macrophytes (Reddy and DeBusk, 1987; Pietro et al., 2006).

As for organic compound content, mean values of lipids obtained in this study varied between $29 \mathrm{mg} \cdot \mathrm{g}^{-1} \mathrm{DW}$ in $E$. densa and $107 \mathrm{mg} \cdot \mathrm{g}^{-1} \mathrm{DW}$ in $N$. marina (Figure 5). Higher values than the ones obtained in this study were observed by Dembitsky et al.(1992) for $C$. demersum from Volga River (120 mg.g $\left.{ }^{-1} \mathrm{DW}\right)$ and for Chara from Caspian Sea 


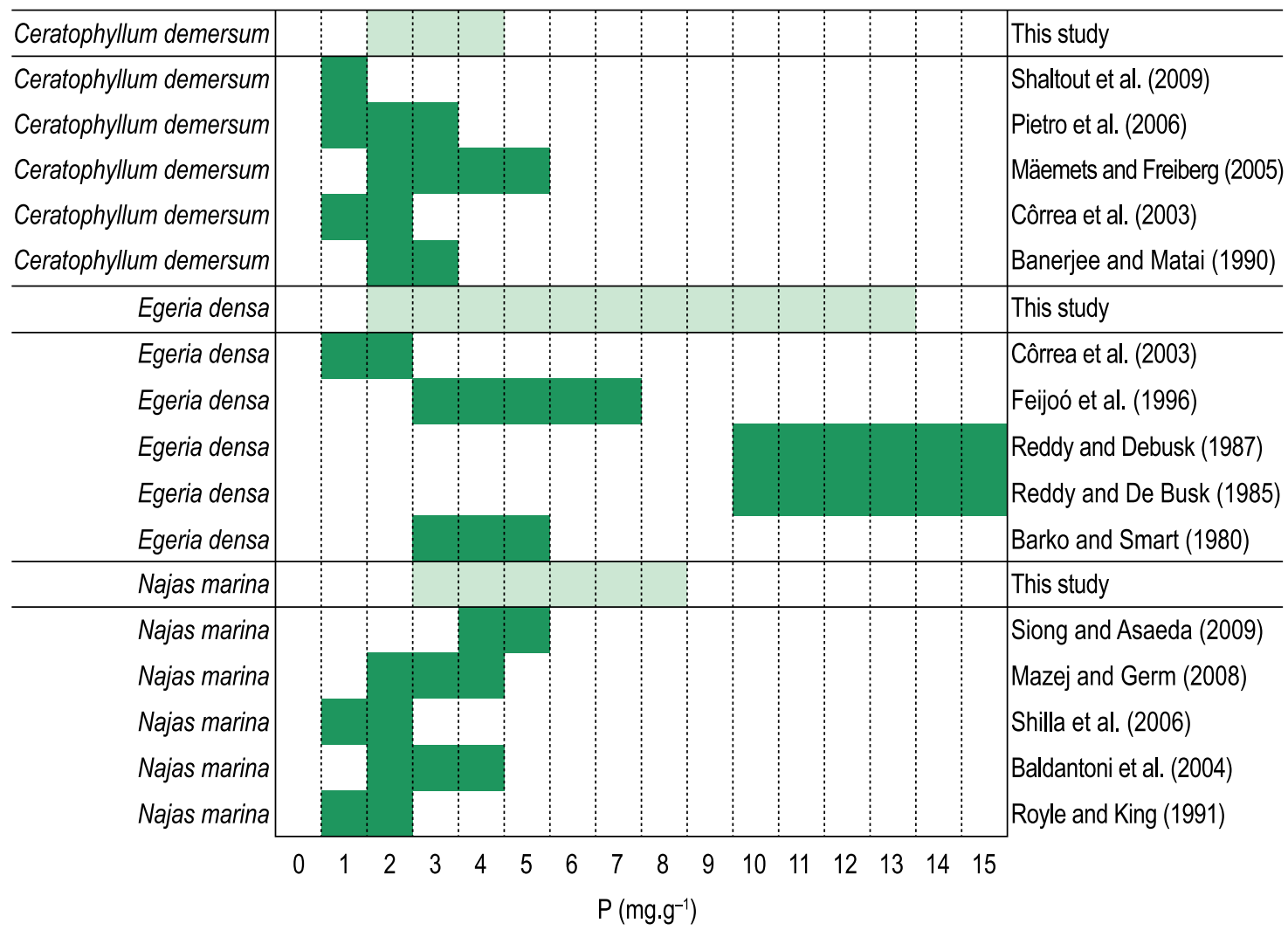

Figure 8. Phosphorus content in macrophytes, expressed as milligram per gram of dry matter (mg. $\left.\mathrm{g}^{-1}\right)$, using data from this study and from literature.

(Dembitsky et al., 1993 - 73 mg.g ${ }^{-1} \mathrm{DW}$ ). Lipids and soluble carbohydrates can readily be used by many organisms, which constitute a major source of energy in the aquatic environment with a high recycling rate (Stabel, 1977). These two organic compounds presented the highest variations among the studied periods with significant increases for C. demersum (about 5 times) in the rainy season. These differences indicate acceleration of productive metabolic activity during the rainy period and/or higher consumption of these compounds during the dry period. Consequently, rainy season is the period for carbohydrates accretion and levels declined during the dry season because respiration rates are higher than photosynthesis at this instance (Evans et al., 1986). The maintenance of alkaline $\mathrm{pH}$ values, dissolved oxygen super-saturation and $\mathrm{CO}_{2}$ sub-saturation in Campelo Lagoon in the rainy period can be attributed to high rates of photosynthesis (Pierini and Thomaz, 2004; Bini et al., 2010), mainly by submerged aquatic macrophytes, once chlorophyll- $a$ values decreased significantly in this period.
A negative correlated between carbohydrates and nitrogen was measured in $C$. demersum and $E$. densa $(\mathrm{r}=-0.7, \mathrm{p}=0.02)$. This demand of carbohydrates and nitrogen are essential to developing of plant species, respectively, (Kabeya and Sakai 2005) and nutrient accumulation occurs when availability exceeds growth requires. Even non-significantly, a decrease in the mean concentration of carbohydrates, and significantly reduction in lipids content in the plant tissue (about $30 \%$ ) are also observed for $N$. marina (Figure 5), corroborating the different ecological functions attributed to macrophytes studied.

Moreover, maintenance of intense development of submerged aquatic macrophytes and high chlorophyll-a concentrations found in Campelo Lagoon during all year suggest that this lagoon is in the intermediate stage of alternative stable states proposed by Scheffer et al. (1993), showing balance between submerged macrophyte and phytoplankton community dominance. The maintenance of turbid waters densely vegetated, as observed in Campelo Lagoon is common in brackish waters, explaining visual dominance of $E$. densa in Campelo Lagoon. 


\section{Acknowledgements}

We gratefully acknowledge Valéria Amado for English revision. This paper is a contribution of the Graduate Program of Ecology and Natural Resources of UENF. This study was funded by UENF and FAPERJ (E-26/150.644/2001).

\section{References}

ARAVIND, P. and PRASAD, MNV. 2005. Zinc mediated protection to the conformation of carbonic anhydrase in cadmium exposed Ceratophyllum demersum L. Plant Science, vol. 169, no.1, p. 245-254.

BALDANTONI, D., ALFANI A., DI TOMMASI, P., BARTOLI, G. and DE SANTO, AV. 2004. Assessment of macro and microelement accumulation capability of two aquatic plants. Environmental Pollution, vol. 130, no. 2, p. 149-156.

BANERJEE, A. and MATAI, S. 1990. Composition of Indian aquatic plants in relation to utilization as animal forage. Journal of Aquatic Plant Management, vol. 29, no. 1, p. 69-73.

BARKO, JW. and SMART, RM. 1980. Mobilization of sediment phosphorus by submersed freshwater macrophytes. Freshwater Biology, vol. 10, no. 1, p. 229-238.

BARKO, JW. and SMART, RM. 1981. Comparative influences of light and temperature on the growth and metabolism of selected submersed freshwater macrophytes. Ecological Monographs, vol. 51, no. 2, p. 219-236.

BARKO, JW., GUNNISON, D. and CARPENTER, SR. 1991. Sediments interactions with submerged macrophyte growth and community dynamics. Aquatic Botany, vol. 41, no. 1-3, p. 41-65.

BENOÎT, O., DEMARS, L. and EDWARDS, AC. 2007. Tissue nutrient concentrations in freshwater aquatic macrophytes: high inter-taxon differences and low phenotypic response to nutrient supply. Freshwater Biology, vol. 52, no. 11, p. 2073-2086.

BERNARDES, MC. and BARROSO, LV. 1995. Efeitos da ação humana sobre as lagoas. Revista Ecologia e Desenvolvimento, $58 \mathrm{p}$.

BINI, LM., THOMAZ, SM. and CARVALHO, P. 2010. Limnological effects of Egeria najas Planchon (Hydrocharitaceae) in the arms of Itaipu Reservoir (Brazil, Paraguay). Limnology, vol. 11, no. 1, p. 39-47.

CARMOUZE, JP. 1994. O metabolismo dos ecossistemas aquáticos: fundamentos teóricos, métodos de estudo e análises químicas. São Paulo: Edgard Blucher/ FAPESP. $254 \mathrm{p}$.

CARR, GM., DUTCHIE, HC. and TAYLOR, WD. 1986. Models of aquatic plant productivity: a review of the factors that influence growth. Aquatic Botany, vol. 59 , no. 1, p. 195-215.
Centro de Informaçóes e Dados do Estado do Rio de Janeiro - CIDE. 1997. Título da obra. Editora? Secplan, Rio de Janeiro. 78 p.

CORRÊA, MR., VELINI, ED. and ARRUDA, DP. 2003. Composição química e bromatológica de Egeria densa, Egeria najas e Ceratophyllum demersum. Planta Daninha, vol. 21, no. 1, p. 7-13.

DELGADO, O., BALLESTEROS, E. and VIDAL, M. 1994. Seasonal variation in tissue nitrogen and phosphorus of Cystoseira mediterranea Sauvageau (Fucales, Phaeophyceae) in the northwestern Mediterranean sea. Botanica Marina, vol. 37, no. 1, p. 1-9.

DEMBITSKY, VM., REZANKA, T.and ROZENTSVET, OA. 1993. Lipid composition of three macrophytes from the Caspian Sea. Phytochemistry, vol. 33, no. 5, p. 1015-1019.

DEMBITSKY,VM., ROZENTSVET, OA., ZHUIKOVA, VS., VASILENKO, RF. and KASHIN, AG. 1992. Lipid composition of freshwater macrophytes from the Volga river estuary. Phytochemistry, vol. 31, no. 9, p. 3259-3261.

DUBOIS, M., GILLES, KA., HAMILTON, JK., REBERS, PA. and SMITH, F. 1956. Colorimetric method for determination of sugars and related substances. Analytical Chemistry, vol. 28, no. 3, p. 350-356.

ESTEVES, B.S., TAOUIL, A. and SUZUKI, M.S. 2005. Nutrient composition of macroalgae and macrophytes of the Açu lagoon, Rio de Janeiro State, Brazil. Acta Limnologica Brasiliensia, vol. 17, no. 3, p. 233-244.

EVANS, AS., WEBB, KL. and PENHALE, PA. 1986. Photosynthetic temperature acclimation in two coexisting seagrasses, Zostera marina L. and Ruppia maritima L. Aquatic Botany, vol. 24, no. 1, p. 185-197.

FEIJOÓ, C., GARCÍA, M., MOMO, F. and TOJA, J. 2002. Nutrient absorption by the submerged macrophyte Egeria densa Planch.: effect of ammonium and phosphorus availability in the water column on growth and nutrient uptake. Limnetica, vol. 21, no. 1, p. 3-104.

Fundação Instituto de Desenvolvimento Econômico e Social - FIDERJ. 1978. Indicadores climatológicos do estado do Rio de Janeiro. Rio de Janeiro, 155 p. Série SIPE.

GERLOFF, GC. and KROMBHOLZ, PH. 1966. Tissue analysis as a measure of nutrient availability for the growth of angiosperm aquatic plants. Limnology and Oceanography, vol. 11, no.1, p. 529-537.

GOULDER, R. and BOATMAN, DJ. 1971. Evidence that nitrogen supply influences the distribution of a freshwater macrophyte Ceratophyllum demersum. Journal of Ecology, vol. 59, no. 3, p. 783-791. 
GRAN, G. Determination of equivalent point in potentiometric titration. 1952. The Analyst, vol. 77, no. 920, p. 661-671.

GRASSHOFF, K., EHRHRDT, M. and KREMLING, K. 1983. Methods of seawater analysis, 2 nd edition. Weinheim: Verlag Chemie. 419 p.

GREENWAY, M. and WOOLEY, A. 1999. Constructed wetlands in Queensland: performance efficiency and nutrient bioaccumulation. Ecological Engineering, vol. 12 , no. 1-2, p. 39-55.

HAUENSTEIN, E. and RAMÍREZ, C. 1986. The influence of salinity on the distribution of Egeria densa in the Valdivia river basin, Chile. Archiv für Hydrobiologie, vol. 107, no. 1, p. 511-520.

HERBRETEAU, F., COIFFARD, LJM., DERRIEN, A. and ROECK-HOLTZHAUER, Y. 1997. The fatty acid composition of five species of macroalgae. Botanica Marina, vol. 40, no. 1-6, p. 25-28.

HOWARD, RJ. and RAFFERTY, DW. 2006. Clonal variation in response to salinity and flooding stress in four marsh macrophytes of the northern Gulf of Mexico, USA. Environmental and Experimental Botany, vol. 56, no. 3, p. 301-313.

JEPPESEN, E., SONDERGAARD, MA., SONDERGAARD, MO. and CHRISTOFFERSEN, K. 1998. The Structuring Role of Submerged Macrophytes in Lakes. New York: Springer. 452 p.

KABEYA, D. and SAKAI, S. 2005. The relative importance of carbohydrate and nitrogen for the resprouting ability of Quercus crispula seedlings. Annals of Botany, vol. 96, no. 1, p. 479-488.

KASIGE, A. and TAKASHI, A. 2009. Carbon and nitrogen partitioning in the freshwater submerged macrophyte Vallisneria gigantea in response to ultraviolet-B irradiance. Aquatic Ecology, vol. 43, no. 2, p. 313-322.

KIPRIYANOVA, LM., YERMOLAEVA, NI., BEZMATERNYKH, DM., DVURECHENSKAYA, SY. and MITROFANOVA, EY. 2007. Changes in the biota of Chany Lake along a salinity gradient. Hidrobiologia, vol. 576, no. 1, p. 83-93.

KUFEL, L. and OZIMEK, T. 1994. Can Chara control phosphorus cycling in Lake Luknajno (Poland). Hydrobiologia, vol. 275-276, no. 1, p. 277-283.

MÄEMETS, H. and FREIBERG, L. 2005. Long- and short-term changes of the macrophyte vegetation in strongly stratified hypertrophic Lake Verevi. Hydrobiologia, vol. 547, no. 1, p. 175-184.

MAZEJ, Z. and GERM, M. 2008. Seasonal changes in the contents of nutrients in five macrophyte species from the lake Velenjsko jezero (Slovenia). Acta Biologica Slovenica, vol. 51, no. 1, p. 3-11.

MORENO-OSTOS, E., SILVA, SLR., VICENTE, I. and CRUZ-PIZARRO, L. 2007. Interannual and between-site variability in the occurrence of clear water phases in two shallow Mediterranean lakes. Aquatic Ecology, vol. 41, no. 1, p. 285-297.

NI, L. 2001. Effects of water column nutrient enrichment on the growth of Potamogeton maackianus A. Been. Journal of Aquatic Plant Management, vol. 39, no. 1, p. 83-87.

NUSCH, EA. and PALME, G. 1975. Bilogische methoden für die Praxis der gewässeruntersuchung. Gmf. Wasser/Abwasser, vol. 116, no. 1, p. 562-565.

OZIMEK, T., GULATI, RD. and VAN DONK, E. 1990. Can macrophytes be useful in biomanipulation of lakes? The Lake Zwemlust example. Hydrobiologia, vol. 200/201, no. 1, p. 399-407.

PIERINI, SA. and THOMAZ, SM. 2004. Effects of inorganic carbon source on photosynthetic rates of Egeria najas Planchon and Egeria densa Planchon (Hydrocharitaceae). Aquatic Botany, vol. 78, no. 2, p. 135-146.

PIETRO, KC., CHIMNEY, MJ. and STEINMAN, AD. 2006. Phosphorus removal by the Ceratophyllum/ periphyton complex in a south Florida (USA) freshwater marsh. Ecological Engineering, vol. 27, no. 4, p. $290-300$.

PINOCHET, D., RAMÍREZ, C., MacDONALD, R. and RIEDEL, L. 2004. Concentraciones de elementos minerales en Egeria densa Planch. Colectada en el santuario de la naturaleza Carlos Anwandter, Valdivia, Chile. Agro Sur, vol. 32, no. 2, p. 80-86.

PIOLA, RF, SUTHERS, IM. and RISSIK, D. 2008. Carbon and nitrogen stable isotope analysis indicates freshwater shrimp Paratya australiensis Kemp, 1917 (Atyidae) assimilate cyanobacterial accumulations. Hydrobiologia, vol. 608, no. 1, p. 121-132.

POMPÊO, MLM. and MOSCHINI-CARLOS, V. Macrófitas aquáticas e perifiton, aspectos ecológicos e metodológicos. São Carlos: RiMa, 2003. 130 p.

REDDY, KR. and DEBUSK, WF. 1985. Nutrient removal potential of selected aquatic macrophytes. Journal of Environmental Quality, vol. 14, no. 1. p. 459-462.

REDDY, KR. and DEBUSK, WF. 1987. Nutrient storage capabilities of aquatic and wetland plants. In Reddy, KR., Smith, WH., eds. Aquatic Plants for Water Treatment and Resource Recovery. Orlando: Magnolia Publishing. p. 337-357.

ROYLE, RN. and KING, RJ. 1991. Aquatic macrophytes in Lake Liddell New South Wales Australia biomass nitrogen and phosphorus status and changing distribution from 1981 to 1987. Aquatic Botany, vol. 41, no. 4, p. 281-298.

SCHEFFER, M., HOSPER, SH., MEIJER, M-L., MOSS, B. and JEPPESEN, E. 1993. Alternative equilibria in shallow lakes. Trends in Ecology and Evolution, vol. 8, no. 1, p. 275-279.

SHALTOUT, KH., GALAL, TM. and EL-KOMI, TM. 2009. Evaluation of the nutrient status of some 
hydrophytes in the water courses of Nile Delta, Egypt. Journal of Botany, vol. 2009, no. 1, p. 1-11.

SHILLA, DA., ASAEDA, T., KIAN, S., LALITH, R. and MANATUNGE, J. 2006. Phosphorus concentration in sediment, water and tissues of three submerged macrophytes of Myall Lake, Australia. Wetlands Ecology and Management, vol. 14, no. 6, p. 549-558.

SIONG, K. and ASAEDA, T. 2009. Effect of magnesium on charophytes calcification: implications for phosphorus speciation stored in biomass and sediment in Myall Lake (Australia). Hydrobiologia, vol. 632, no. 1, p. 247-259.

SPENCER, DF., RYAN, FJ. and KSANDER, GG. 1997. Construction costs for some aquatic plants. Aquatic Botany, vol. 56, no. 3-4, p. 203-214.

STABEL, HH. 1977. Gebundene kohlen hydrate als stabile komponete in Schohsee und Scenedesmus- kulture. Archiv für Hydrobiologie, vol. 53, no. 1, p. 159-254.

STRICKLAND, JDH. and PARSONS, TR. 1978. A practical handbook of seawater analysis. $2 \mathrm{nd}$ ed. Ottawa. 311 p.

WANG, MT., ZHAO, ZG., DU, GZ. and HE, YL. 2008. Effects of light on the growth and clonal reproduction of Ligularia virgaurea. Journal of Integrative Plant Biology, vol. 50, no. 8, p. 1015-1023.

YARROW, M., MARÍN, VH., FINLAY, M. TIRONI, A., DELGADO, LE. and FISCHER, F. 2009. The ecology of Egeria densa Planchon (Liliopsida: Alismales): a wetland ecosystem engineer? Revista Chilena de História Natural, vol. 82, no. 1, p. 299-313.

Received: 02 June 2010 Accepted: 27 September 2010 